\title{
Analysis of Shared Value Added in the Poultry Sector: Case of the City of Yaounde
}

\author{
http://doi.org/10.21272/fmir.3(2). 102-114.2019
}

\section{Boutchouang Nghomsi Chanceline}

Economist, Consultant, Cameroon

\begin{abstract}
The purpose of this paper is to estimate and analyze the repartition of the added value between the agents of the poultry chain in Yaoundé. To achieve this, we have used the analysis of global value chain and governance typology used by Gereffi and al and the New Institutional Economy of Williamson. Our studies were based on an internship at Interprofession Avicole du Cameroun (IPAVIC) where we did interview with the actors envolved in that sector. The economic evaluation of the generated added value part by every actor of the poultry sector has been done by two values chains (broiler and eggs of consumption) selected. The theories used in this research helped us to study the behaviour of the agents including the coordination method that ruled their transactions. As a result, we found that the processing and production segments have the margins and drive the respective value chains. It has also been shown that some mode of coordination of transactions between actors of the sector have a significant influence on the distribution of the value added in the poultry sector.
\end{abstract}

Keywords: value added, chain, Global chain of value, governance typology, New Institutional Economy. JEL Classification: G21, G33, G32, C13, C58.

(C) The Authors, 2019. This article is published with open access at Sumy State University.

Cite as: Boutchouang Nghomsi Chanceline. (2019). Analysis of Shared Value Added in the Poultry Sector: Case of the City of Yaounde. Financial Markets, Institutions and Risks, 3(2), 102-114. http://doi.org/10.21272/fmir.3(2). 102-114.2019

\section{Introduction}

Chicken meat is the most important component of the poultry contribution to the meat diet, providing $4 \mathrm{~kg} / \mathrm{in}-$ habitant/year (Teleu and Ngatchou, 2006), ie $17 \%$ of the total $13.07 \mathrm{~kg}$ of consumption. annual meat per capita (ACDIC, 2005). The poultry sector plays a very important role in the Cameroonian economy and in improving the living conditions of the populations by providing income to the households through the marketing activity of the sale of chicken. At the macroeconomic level, the poultry (broiler) flock is estimated at a production of $50,000,000$ head (broiler) and 1,350,000,000 eggs [IPAVIC, 2013] in the modern sector and more than 25000 000 heads in the traditional system [MINEPIA (3), 2009]. With more than 320,000 jobs created in the sector, it covers $14 \%$ of animal protein requirements. Chicken meat therefore occupies an important place in the diet of Cameroonians. Singularly used for ceremonies (festivals, weddings, funerals), a few years ago, chicken meat has become progressively a banal commodity in the same way as that of beef. The increase in annual per capita consumption has increased from $2 \mathrm{~kg}$ in 1984 to $4 \mathrm{~kg}$ in 2005 (Teleu and Ngatchou, 2006). An annual increase in consumption is correlated with an increase in the population. For a total contribution estimated at nearly $3 \%$ of GDP (4) [PACA (5), 2013], the poultry meat sector does not represent a pillar of the Cameroonian economy. However, it remains a component of food security, although there is a deficit of 40,000 tons in 2009 (MINEPIA, 2009) and a significant source of agricultural income. The sector generates an annual net profit estimated at around 15 billion CFA Francs. From an economic point of view, the functioning of the poultry market raises the question of the distribution of added value between the downstream actors of the productive link according to the mode of marketing of poultry products in our markets which is itself very controversial. In fact, it is the analysis of the economic performance of this type of market, the determination of the surplus of consumers and producers, and the institutional mechanisms that can support how the organization methods of the sector impact the distribution of value added. Most analyzes will use the tools of the industrial economy, Gereffi et al.'S $(1994,2005)$ value chain analysis, microeconomics and the new institutional economy. To achieve the desired results, we have the following two main objectives: evaluate the percentage of value added between each segment of the industry; evaluate the link between the coordination modes (arrangements) of the various actors and the added values generated in the sector. 


\section{II.Theoretical frame}

This section presents the context for value-added sharing analysis, the conceptual framework and theories mobilized.

\section{II.1. Context}

For nearly a decade, in the wake of the ban on the importation of frozen chickens in Cameroon, we are witnessing a revival of activities in the poultry sector of the country with several new actors who have integrated it. As the sector has expanded, we are seeing an upsurge of broilers a development of the sector that augurs an economic upturn. At the macroeconomic level, the poultry (broiler) flock is estimated at a production of 50000 000 head (broiler) and 1350000000 eggs (IPAVIC, 2013) in the modern sector and more than 25000000 heads in the traditional system (MINEPIA, 2009). With more than 320,000 jobs created in the sector, it covers $14 \%$ of animal protein requirements. Chicken meat therefore occupies an important place in the diet of Cameroonians. With a contribution of more than 3\% of GDP (PACA, 2013), more than one million Cameroonians are active in the poultry sector. Despite a strong propensity exerting the informal, our objective through this article is to determine the distribution of the added value and also the modes of coordination between the actors of this sector.

\section{II.2. Theoretical and conceptual framework}

The choice of the research question leads to favoring a theoretical framework that makes it possible to take into account both the role of governance in transactions and the factors influencing the performance of the actors involved in them. A certain number of theoretical approaches make it possible to understand the reasons underlying the modes of coordination between the protagonists of the sector and to investigate the economic performance of the sector. We will also appropriate the contributions of the industrial economy through the SBP triptych (Structure-Behavior- Performance), the contributions of the value chain analysis of Gereffi and al $(1994,2005)$ which combines the different methods of analysis of agro-food chains. We adopt this theoretical framework because it supports the interrelationships and dynamics between the actors through the concept of governance. It helps to explain the coordination of actors in value chains with the objective of producing quality goods and, above all, creating added value. We solicit the typology of the GCV which includes the appropriate modes of governance to describe the exchanges observed between the actors. Finally, we will mobilize the work of Oliver Williamson who is interested in the existence of different organizational arrangements chosen by the economic agents to coordinate the production and the exchange, as well as to the arbitration which takes place during the choices. operationalized through the theory of transaction costs.

\section{III.The determinants of value-added sharing in the poultry industry}

The actors of the poultry sector in Cameroon and specifically those of the city of Yaounde are grouped together in formal and informal associations. For the first category, we will find within the Interprofession Avicole du Cameroun, which is the body that oversees the largest producers in the country. In the second category, these actors meet by association according to the markets in which they are implanted, we can mention the Circle of the friends of the poultry of Mvog Ada, the Sellers of chicken of the market of Etoudi, what has allowed to design the cartography of the sector as follows:

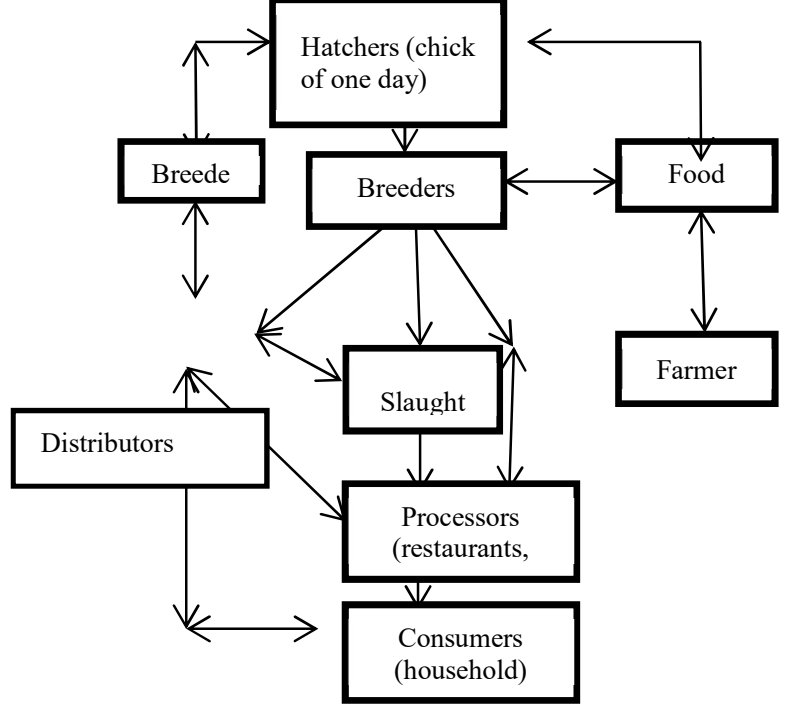

Source: by author.

Figure 3.1 Mapping of the poultry sector in Yaoundé 
Financial Markets, Institutions and Risks, Volume 3, Issue 2, 2019

ISSN (online) - 2521-1242 ISSN (print) - 2521-1250

In this article, we have taken the indicators that will make it possible to evaluate the added value of the sector at each link and also those which will highlight the modes of coordination of the transactions of the activities between the actors of this sector.

\subsection{Locating the study area}

Yaoundé, nicknamed the city of seven hills, is the administrative and political capital of Cameroon since 1922. It is the capital of the Central Region (Cameroon with ten regions) and the Mfoundi department. With a population estimated at over 1,500,000, it is a cosmopolitan city that brings together all the cultural and ethnic sensitivities of Cameroon and foreigners of various nationalities from Africa, Latin America, Asia and the West. It is also the city that records the highest level of consumption of broiler meat and its derivatives.

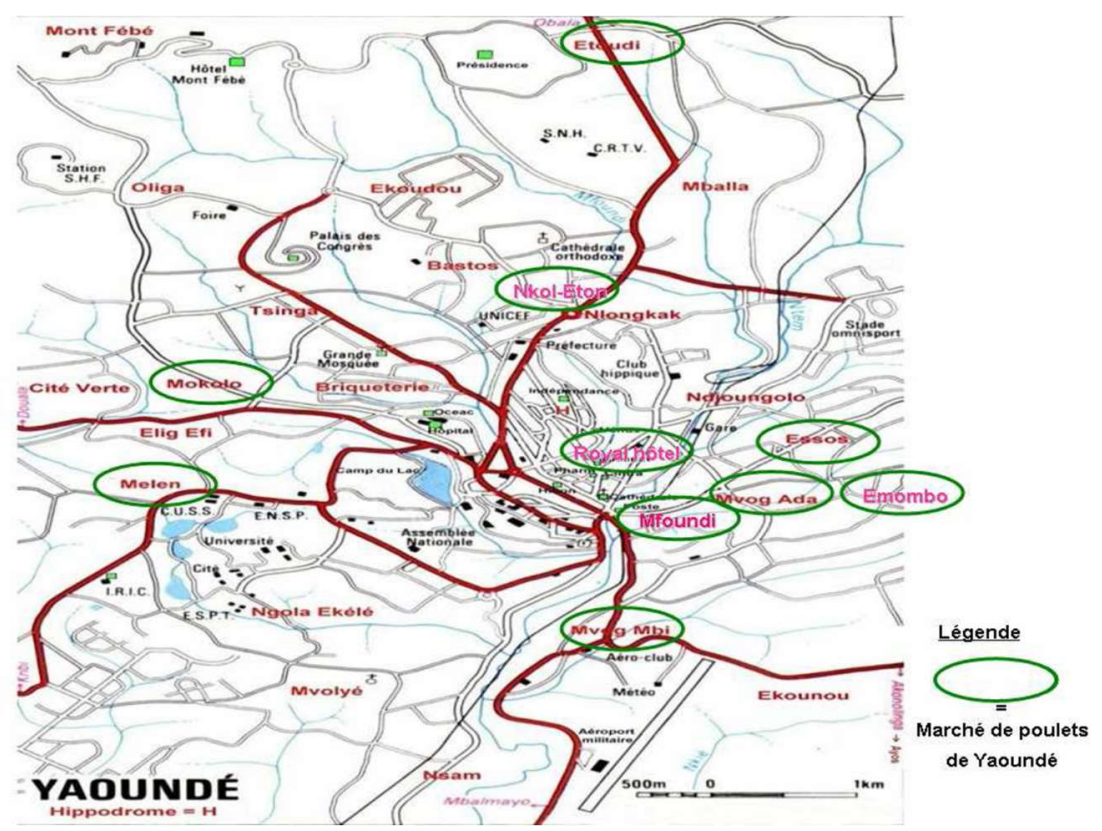

Card 1. Yaoundé Chichken Market (INS, 2005)

As part of this study, we interviewed 110 actors in the sector:

- There are 73 actors for poultry, distributed as follows: 10 producers, 21 distributors, 21 fellers, 21 processors.

- There are 37 actors for eggs, distributed as follows: 11 producers, 11 distributors and 15 processors.

3.2. Indicators of added value and modes of coordination between actors in the poultry sector.

- The distribution of margins: the margins will be determined according to the cost structure of the poultry industry and the data we obtained from our respondents;

- The influence of the type of activity;

- Arrangements between actors in the sector.

The actors of this sector devote more time to their activities so, their availability is not obvious, it was necessary in most cases to go to the places where they carry out their activities. Moreover, many of them do not control the costs associated with the production and marketing of poultry products. Apart from this, the data collection was not at all easy because of the reluctance of some producers to use these data against them, some even reported the tax adjustments that were inflicted on some of theirs, failing.

\subsection{Methodological Approaches}

The analytical tools used in this case range from economic analysis to statistical analysis of data from surveys of industry players. This will be done firstly by the presentation of the two theoretical models, then we will specify the so-called models.

\subsubsection{Analysis of financial performance in the poultry sector}

The analysis of the economic viability of the value chain is an important element for the actors of this sector of activity, since it makes it possible to evaluate the chain's performance in terms of economic efficiency and relates to the evaluation of the value chain. global added values produced by the chain and actions of the 
different stages, production and marketing costs (or transaction costs) and operator performance (use of productive capacity, productivity and profitability).

As a result, several profitability ratios are calculated as part of this analysis:

Added Value (AV)

$\mathrm{AV}=\mathrm{TP}-\mathrm{IC}$ with $\mathrm{TP}=\mathrm{VC}+\mathrm{FC}$ and $\mathrm{CI}=\mathrm{W}$

Where TP: Total Production, CI: Intermediate Consumption, VC: Variable Cost, FC: Fixed Cost.

Calculation of marketing costs: handling, transport and processing costs (MC)

Calculation of the $\mathrm{MBC}=\mathrm{PP}-\mathrm{MC}$ with Use 1:

GM* Activity Volume = Gross Margin of the Operator GM/Product (broiler and egg consumption)

Use 2:

- Margin rate calculation: MR / Producer Price or PP.

- Calculate the ratio MR / Value Created

\subsubsection{Statistical analysis method}

\subsubsection{Analysis tools}

Statistical analysis of data collected in the field required the use of some statistical tools. Descriptive statistics included a summary of all the information observed. The one-way analysis of variance (Anova) was used to determine the change in margin generated by activity; and a second two-way analysis of variance performed to assess the influence of the arrangements between the actors on the generated margins.

\subsubsection{Statistical software}

EXCEL 2010: Descriptive statistics, curves and Histograms of averages and frequencies. Graphpad prism 5: One-way variance analysis.

\subsubsection{Analysis of variance}

An analysis of variance is a statistical test carried out in order to evaluate the effect of the modalities of a factor on a response variable studied.

\section{- The postman}

We call factor any series of elements of the same nature conditioning the phenomenon studied. In our case, the activity conducted and the other dependent variables are the different elements that constitute a factor called levels or modalities. In our case (Egg Producer, Egg Dispenser, Egg Transporter, Feller, etc.) for the activity factor conducted and (type of relationship, type of payment, location, ... etc.) for the factor characterizing the other dependent variables.

- The answer

The answer here is the variable of interest studied. The one on which the effect of the modalities of the factor must be evaluated. In our case the answer is the margin generated by the respondents. The analysis of variance will therefore consist in evaluating the effect of the activity carried out and the other dependent variables on the margin generated by the respondents.

\subsection{Realization of the anova}

After collecting the field data from the respondents. Margin values are obtained for each respondent by activity conducted and for all other dependent variables (relationship type, payment method, etc.). Yij is the value of the margin obtained on the ith activity and the jth dependent variable. The objective is to know if the margins generated by the respondents are a function of the activities and the different interrelations between the actors of the sector. We then pose two hypotheses:

A first hypothesis is called H0: Margins are correlated with activity and arrangements. A second hypothesis is called H1: margins are not correlated with activity and arrangements. In this case only the margins of the same activity or the same dependent variable have substantially the same value. We denote $\mu 1$ the margin 
generated by activity 1 or the dependent variable 1 and $\mu 2$ the margin generated by activity 2 or the dependent variable 2 . We posit $\mu \mathrm{i}=\mu+\alpha \mathrm{i}$, where $\alpha \mathrm{i}$ is the effect of activity $\mathrm{i}$ or the dependent variable $\mathrm{i}$. It must be decided whether $\mathrm{H} 0$ or $\mathrm{H} 1$ are retained from the data collected. The data are analyzed using the model $\mathrm{Yij}=$ $\mu+\alpha \mathrm{i}+\varepsilon \mathrm{ij}$. NB: $\varepsilon \mathrm{ij}$ is the residual error. It is estimated $\mu$ by $\mathrm{X}^{-}=(\Sigma \mathrm{ijYij}) / \mathrm{N}$, we estimate $\alpha \mathrm{i}$ by $\sigma=(\Sigma \mathrm{j} Y \mathrm{ij}) /$ $\mathrm{n}-\mathrm{X}^{-} \cdot \mathrm{X}^{-}$is the average of all margins (general average) and $\sigma$ is the difference between the average of the margins of activity $i$ or of the dependent variable $i$ and the general average.

To decide the hypothesis to retain ( $\mathrm{H} 0$ the $\alpha \mathrm{i}$ are all zero, $\mathrm{H} 1$ the $\alpha \mathrm{i}$ are not all null), we perform an analysis of variance:

- The dispersion of the effects of the activities or of the dependent variables is estimated, they will be all the greater as the $\alpha$ i will be different;

- The dispersion due to random fluctuations, which serves as a reference base, is estimated; it will be the greater the larger the residues will be;

And we compare the two dispersions.

The dispersion of the effects of the activity is estimated by what is called the sum of the Total squares of $t$ (STS) and the dispersion due to the random fluctuations which serves as the reference base is estimated by what is called the sum of the residual squares. (SRS).

We obtain these estimates knowing that: $\mathrm{Yij}=\mathrm{Xi}+\mathrm{Ai}+\mathrm{Eij}$ and we show that: $\mathrm{T}=\mathrm{STS}+\mathrm{SRS}$

But we can not directly compare the two sums of squares of deviations. They must be divided by their respective numbers of degrees of freedom, that is, the number of independent values that compose them: $t-1$ for STS and $\mathrm{n}-1$ for SRS with $\mathrm{t}=$ number of treatments (activities carried out or dependent variables) and $\mathrm{n}=$ number of respondents. We are then interested in the probability that an $\mathrm{F}$ exceeds the value actually calculated. If this probability is lower than a previously fixed threshold, equal to $\alpha$ (for example $5 \%$ or $1 \%$ ), we say that the margins generated by the different activities or dependent variables are significantly different at the $\alpha$ level. This means that we reject $\mathrm{H} 0$ and retain $\mathrm{H} 1$. On the contrary, if this probability is greater than $\alpha$, we say that the margins generated are not significantly different at the $\alpha$ level. This means that we accept $\mathrm{H} 0$ and reject H1.

\subsubsection{Description of the variables}

In the table below, we highlight the variables that will make it necessary to carry out our analysis on both economic and statistical performance.

Table 3._Presentation and description of variables

\begin{tabular}{|l|l|l|}
\hline Variables & Définition & Measure \\
\hline Average commercial Margin & $\begin{array}{l}\text { Value added after withdrawal of intermediate Con- } \\
\text { sumption }\end{array}$ & continue \\
\hline Variance & Average deviation to the average of the margin & continue \\
\hline Relationship & Link between agents sector & $\begin{array}{l}\text { Binary variable } \\
1 \text { if professional } \\
0 \text { if proximity }\end{array}$ \\
\hline Financial support between actors & Production fiancing and/or support of a partner & $\begin{array}{l}\text { Variable binaire } \\
1 \text { si oui } \\
0 \text { sinon }\end{array}$ \\
\hline Location & accomodation of supply & $\begin{array}{l}\text { Binary value } \\
0 \text { if in the city of Yaoundé } \\
1 \text { if no }\end{array}$ \\
\hline Mode of Transport & & $\begin{array}{l}0 \text { if leasing } \\
1 \text { if owner of a means of transport }\end{array}$ \\
\hline Contractualization & Means of transport & $\begin{array}{l}0 \text { if verbal } \\
1 \text { if formal }\end{array}$ \\
\hline Transaction (payment) mode & Written support that regulates the interaction be ben agents of the sector & $\begin{array}{l}\text { if loan } \\
1 \text { si cash }\end{array}$ \\
\hline
\end{tabular}

Source : Data survey.

\subsubsection{Poultry sector Margin distribution}

The margins are determined under the cost structure of the poultry sector and others data of the survey. 
Table 3.1. Margin distribution between poultry sector actors

\begin{tabular}{|c|c|c|c|}
\hline Title & Actor & Chicken meat & Eggs \\
\hline \multirow[t]{5}{*}{ Fixed Cost } & Producers & 1463.42 & 44.11 \\
\hline & Distributors & 0.978 & 0.18 \\
\hline & Fellers & 0.59 & 59.33 \\
\hline & Processors & 6.75 & \\
\hline & Total & 1471.74 & 103.44 \\
\hline \multirow[t]{5}{*}{ Variable Cost } & Producers & 140.65 & 0.165 \\
\hline & Distributors & 60.46 & 0.17 \\
\hline & Fellers & 5.16 & \\
\hline & Processors & 235.28 & \\
\hline & Total & 456.99 & \\
\hline \multirow[t]{5}{*}{ Workforce } & Producers & 98.63 & 0.13 \\
\hline & Distributors & 8.89 & 0.19 \\
\hline & Fellers & 17.94 & \\
\hline & Processors & 94.75 & 0.32 \\
\hline & Total & 220.19 & \\
\hline \multirow[t]{4}{*}{ Total Cost } & $\begin{array}{c}\text { Producers } \\
\text { Distributors }\end{array}$ & $\begin{array}{c}1702.69 \\
289.12 \\
\end{array}$ & 44.11 \\
\hline & Fellers & 9.4 & 0.48 \\
\hline & Processors & 285.36 & \\
\hline & Total & 2074.4 & 44.59 \\
\hline \multirow[t]{7}{*}{ Margin/division } & Producers & 294.21 & 5.28 \\
\hline & Distributors & 216.57 & 5.72 \\
\hline & & & - \\
\hline & & & 15.21 \\
\hline & Fellers & 125.54 & \\
\hline & Processors & 1238.35 & \\
\hline & Total Margin & 1947.35 & 26.21 \\
\hline
\end{tabular}

Source: Survey data. author's estimate.

Observation: When reading the table above. we obtain a total margin of about 1947.35 FCFA / chicken and 26.21 FCFA / egg. The breakdown shows that the producer segment is doing well with 294.21 FCFA / chicken and 5.28 FCFA / egg. The distribution segment receives 216.57 FCFA / chicken and 5.72 FCFA / egg. then follows the segment of the fellers which captures 198.22 FCFA / chicken and the segment of the processors with 1238.35 FCFA / chicken and 15.21 FCFA / egg.

We can easily deduce that the link in the processor drives the two value chains of the poultry sector. To better illustrate this result. we will represent it in two diagrams according to the value chains of the sector.

\section{Margin}

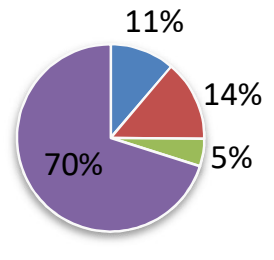

$$
\begin{aligned}
& \text { - Producers } \\
& \text { - Distributors } \\
& \text { - Fellers } \\
& \text { - Processors }
\end{aligned}
$$

Figure 3.1: Margin distribution of each actor in the broiler value chain.

Source: Data from survey.

The diagram above shows the share of margin captured by processors equivalent to more than $70 \%$ of the total generated. followed by distributors. producers and fellers. We deduce that the broiler value chain is driven by the processors in terms of the percentage of each player's margins. 


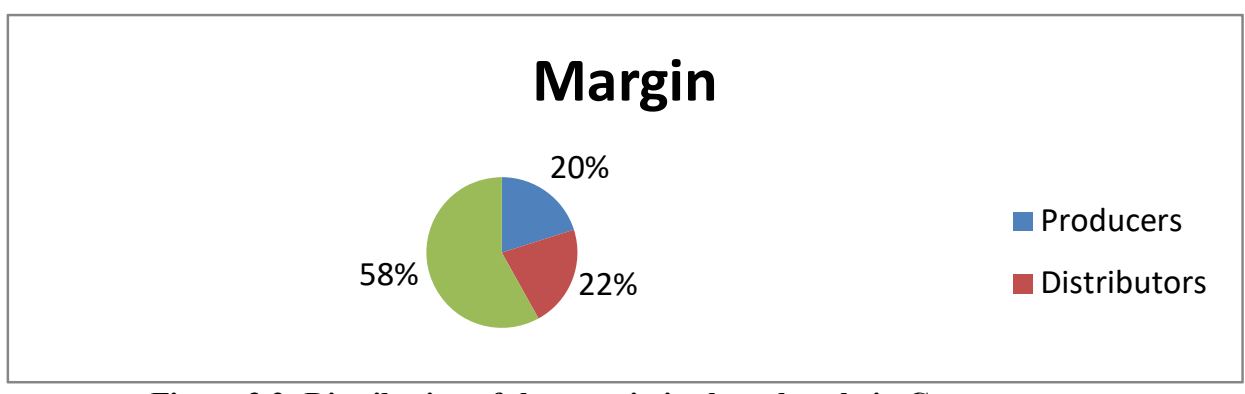

Figure 3.2: Distribution of the margin in the value chain Consumer egg

Source: Data from survey.

Similarly. by observing the egg value chain of consumption. we observe that the link of processors is awarded nearly $60 \%$ of margins. followed by distributors and producers.

Table 3.2: Calculation of Value Added (AV) generated by the commodity chain $\mathrm{AV}=$ Gross Value of the Product - Intermediate Consumption.

\begin{tabular}{|c|c|c|c|}
\hline Title & Actor & Chicken Meat & Eggs \\
\hline \multirow[t]{2}{*}{ Intermediate } & Producers & 1702.69 & 0.25 \\
\hline & Distributors & 9.96 & 0.13 \\
\hline \multirow[t]{3}{*}{ Consumption (IC) } & Fellers & 27.32 & \\
\hline & Processors & 421.99 & 0 \\
\hline & Total & 2162.19 & 0.58 \\
\hline Added Value & Producers & 296.62 & 5.28 \\
\hline \multirow[t]{4}{*}{$(\mathrm{AV})$} & Distributors & 368.72 & 5.72 \\
\hline & Fellers & 198.22 & - \\
\hline & Processors & 1852.97 & 15.21 \\
\hline & Total & 2643.85 & 26.21 \\
\hline \multirow{5}{*}{$\begin{array}{l}\text { Global Value Added } \\
\text { On Added Value By } \\
\text { Actor (GVA/Ava) } \%\end{array}$} & Producers & 11.21 & 20.15 \\
\hline & Distributors & 13.95 & 21.82 \\
\hline & Fellers & 4.74 & - \\
\hline & Processors & 70.10 & 58.03 \\
\hline & Total & 100 & 100 \\
\hline
\end{tabular}

Source: Data from survey. author's estimate.

From Table 3.2. we can analyze the value chain of the poultry sector in the city of Yaounde. We note that it generates added values of 2593.85 FCFA / chicken and 26.21 FCFA / egg. The share of these values added by the different actors of the chain is on average of $11.21 \%$ for the producers. $13.95 \%$ for the distributors. $4.74 \%$ for the fellers and $70.10 \%$ for the processors for this which concerns poultry. While at the consumer egg value chain. we have $20.15 \%$ for producers. $21.82 \%$ for distributors and $58.03 \%$ for processors. This leads us to say that the processors control the two value chains of the poultry sector of the city of Yaoundé.

\section{Diagramme of distribution of the Added Value of chicken meat segment}

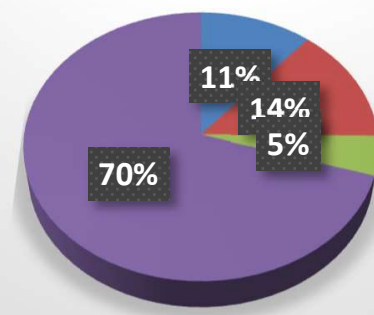

$$
\begin{aligned}
& \text { Producers } \\
& \text { Distributors } \\
& \text { Fellers } \\
& \text { Producers }
\end{aligned}
$$

Figure 3.3: Distribution of the Added value of chicken meat segment

Source: Data survey.

This diagram easily elucidates the results that we have shown in Table 4.2 . With more than $70 \%$ of margins captured by the processing link. $11 \%$ for producers. $14 \%$ for distributors and $5 \%$ for fellers. we conclude that processors drive the broiler value chain. 


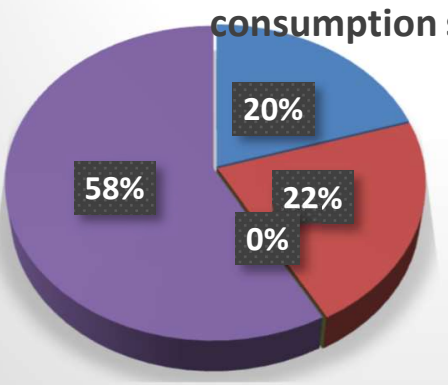

- Producers

Distributors

Fellers

- Producers

Source: Data survey.

Figure 3.4. Distribution of the margin in the chain value of eggs consumption segment

For the actors of the egg product. we have for added value distributed among the various protagonists in descending order $20.15 \%$ for the producers. followed by $21.82 \%$ for the distributors and $58.03 \%$ for the processors. For an overall value created equivalent to 2643.85 / chicken for the chicken product. we have 296.6 FCFA which goes to the producers. 260.72 FCFA for the distributors. 125.54 FCFA for the fellers and 1852.97 FCFA for the processors.

Similarly. for the egg product. the total product of the chain which is equivalent to 26.21 FCFA. the processors are found with 15.21 FCFA. or $58.03 \%$. distributors have a gain equivalent to 5.72 FCFA that is $21.82 \%$ and producers receive close to 5.28 FCFA per egg with a percentage of $20.15 \%$.

Table 3.5: Margin ratio calculated on producer price

\begin{tabular}{|c|c|c|c|}
\hline Designation & Actor & Chicken meat & eggs \\
\hline \multirow[t]{5}{*}{ Margin/segment } & Producers & 294.21 & 5.28 \\
\hline & Distributors & 216.57 & 5.72 \\
\hline & Fellers & 125.54 & - \\
\hline & Processors & 1238.35 & 15.21 \\
\hline & Total Margin & 1947.35 & 26.21 \\
\hline \multirow{5}{*}{$\begin{array}{l}\text { Ratio } \\
\text { Margin/Production } \\
\text { Cost }\end{array}$} & Producers & $17.28 \%$ & $11.84 \%$ \\
\hline & Distributors & $12.69 \%$ & $12.82 \%$ \\
\hline & Fellers & $7.36 \%$ & \\
\hline & Processors & 16.75 & $34.11 \%$ \\
\hline & Total & $54.08 \%$ & $58.77 \%$ \\
\hline
\end{tabular}

Source: Data survey. author's estimate.

Observation:

The table above shows the proportion of the margin in the cost of production of each product from the two sectors. For the producers. it corresponds respectively to $17.28 \%$ and $11.84 \%$. for the distributors. we have $12.69 \%$ and $12.82 \%$. that of the fellers of the broilers corresponds to $7.36 \%$ and for the link of the processor. we get $16.75 \%$ and $34.11 \%$.

Table 3.6. Added Value Margin Ration Created

\begin{tabular}{|c|c|c|c|}
\hline Designation & Actor & Chicken meat & eggs \\
\hline \multirow{5}{*}{$\begin{array}{l}\text { Added Value } \\
\text { (AV) }\end{array}$} & Producers & 296.62 & 7.28 \\
\hline & Distributors & 368.72 & 8.22 \\
\hline & Fellers & 198.22 & - \\
\hline & Processors & 1852.97 & 20.21 \\
\hline & Total & 2643.85 & 35.81 \\
\hline \multirow[t]{5}{*}{ Margin } & Producers & 294.21 & 5.28 \\
\hline & Distributors & 216.57 & 5.72 \\
\hline & Fellers & 125.54 & - \\
\hline & Processors & 1238.35 & 15.21 \\
\hline & Total Margin & 1947.35 & 26.21 \\
\hline \multirow{5}{*}{$\begin{array}{l}\text { Ratio } \\
\text { Value } \\
\text { (AV) }\end{array}$} & Producers & $99.18 \%$ & $72.52 \%$ \\
\hline & Distributors & $58.73 \%$ & $69.59 \%$ \\
\hline & Fellers & $63.33 \%$ & - \\
\hline & Processors & $66.84 \%$ & $72.59 \%$ \\
\hline & Average & $72.02 \%$ & $71.56 \%$ \\
\hline
\end{tabular}

Source: Data survey 
Observation:

In this table. we note that the margin / value added ratios are all higher than $50 \%$ with respective averages of $72.02 \%$ and $71.56 \%$ for each of the value chains in the value chain. In addition. the link in production has a ratio of $99.18 \%$.

\section{Influence of the type of activity on the margin}

The analysis of the influence of the type of activity on the margin in the sector will be made according to the one-way analysis of the variance (ANOVA). In other words. we are using graphpad prism software to show the impact of each type of activity on the margin generated in the industry.

Table 4.7. Analysis of the impact of the type of activity on the margin sector

\begin{tabular}{|l|c|c|c|c|c|c|}
\hline \multicolumn{1}{|c|}{ Variation Source } & $\begin{array}{c}\text { Degree of } \\
\text { liberty (dol) }\end{array}$ & Squares Sums & $\begin{array}{c}\text { Middle Sums } \\
\text { squres }\end{array}$ & $\begin{array}{c}\text { F } \\
\text { calculated }\end{array}$ & $\begin{array}{c}\% \text { of total } \\
\text { variation }\end{array}$ & P. value \\
\hline Activity & 6 & 387300 & 64560 & 1.668 & 12.28 & 0.1006 \\
\hline Arrangement & 11 & 109200 & 9932 & 10.84 & 43.54 & $<0.0001$ \\
\hline Residual (error) & 66 & 392900 & 5954 & & \multicolumn{3}{|c}{} \\
\hline Total & 83 & 889500 & \multicolumn{5}{|l}{}
\end{tabular}

Source: data survey.

Fcal $>$ Flu. the test is statistically significant at $0.5 \%$ and two degrees of freedom. We report a probability P. value $<0.0001$. we have $0.01 \%$ chance to observe the effect of the activity on the margin. This test is statistically significant. It is concluded that the type of activity has an influence on the margin in the poultry sector.

\subsection{Role of institutional arrangements and margin}

The role of the arrangements will be demonstrated by an analysis of two-factor variances. We will test using the graphpad prism software the effect of each arrangement of the actors on the margin generated in the poultry industry.

\subsection{Link between relationship and margin of the sector}

Here it is a question of showing the impact that the relational arrangement can have on the margin of the sector.

Table 4.2: Analysis of the influence of the relation variable on the margin of the sector

\begin{tabular}{|l|c|c|c|c|c|c|}
\hline Factors & dol & SS & MSS & F calculated & $\begin{array}{c}\text { \% of total } \\
\text { variation }\end{array}$ & P. value \\
\hline Activity & 6 & 1393000 & 180200 & 73.36 & 34.95 & $<0.0001$ \\
\hline Type of Relation & 1 & 389200 & 232100 & 94.49 & 12.58 & $<0.0001$ \\
\hline Interaction & 6 & 1081000 & 389200 & 158.4 & 45.01 & $<0.0001$ \\
\hline Residual & 94 & 231000 & 2457 & \multicolumn{2}{|l}{} \\
\cline { 1 - 4 } Total & 107 & \multicolumn{7}{|l}{}
\end{tabular}

Source : Data survey.

When reading the table. we find that the relationship type is $12.58 \%$. the interactions for $34.95 \%$ and the activity $44.01 \%$ of the total variance. The analysis of the variance shows that with $\mathrm{aFcal}=94.49$ for a threshold of 0.0001 . we have a $\mathrm{P}$. value $<0.0001$. So, we have a $0.01 \%$ probability of not observing the effect of the relationship on the margin. This leads us to conclude that the type of relationship (proximity and professional) is statistically significant. it has an influence on the margin in the sector.

\subsection{Margin link to transaction mode variable (payment)}

Table 4.3: Analysis of the influence of the mode of transaction on the margin

\begin{tabular}{|c|c|c|c|c|c|c|}
\hline Factors & dol & SS & MSS & F calculated & $\begin{array}{l}\% \text { of total } \\
\text { variation }\end{array}$ & P. value \\
\hline Activity & 5 & 72240 & 14450 & 1.093 & 5.14 & 0.3711 \\
\hline Payment Mode & 1 & 312700 & 62540 & 4.732 & 22.25 & 0.0008 \\
\hline Interaction & 5 & 3075 & 3075 & 0.2327 & 0.22 & 0.6309 \\
\hline Residual & 77 & 1018000 & 13220 & & & \\
\hline Total & 88 & & & & & \\
\hline
\end{tabular}

Source: Data survey.

When reading the table above. we note that the activity corresponds to approximately $5.14 \%$ of the total variance with a Fcal $=1.093$ at $\mathrm{ddl}=5$. We obtain a $\mathrm{P}$. value $=0.3711$. we conclude this factor is not statistically 
significant and therefore the activity has no influence on the payment method in the sector. Similarly. the payment method satisfies $0.22 \%$ of the total variance with $\mathrm{aFcal}=4.732$ at 1 degree of freedom and a probability $\mathrm{P}$. value $=0.6309$. So, we have a $63.09 \%$ chance of getting a payment method effect on the margin. which shows that the test is not statistically significant.

\subsection{Link of the contractualisation variable with the margin of the actors of the sector}

Table 4.4: Analysis of the influence of the contracting method on the margin

\begin{tabular}{|l|c|c|c|c|c|c|}
\hline \multicolumn{1}{|c|}{ Factors } & dol & SS & MSS & F calculated & $\begin{array}{c}\text { \% of total } \\
\text { variation }\end{array}$ & P. Value \\
\hline Interaction & 6 & 7090 & 1182 & 0.1216 & 0.50 & 0.9935 \\
\hline Activity & 6 & 462000 & 77010 & 7.922 & 32.90 & $<0.0001$ \\
\hline Type of Contract & 1 & 2067 & 2067 & 0.2126 & 0.15 & 0.6457 \\
\hline Residual & 96 & 933200 & 9721 & \multicolumn{3}{|c}{} \\
\hline Total & 109 & \multicolumn{5}{|l}{}
\end{tabular}

Source: Data survey.

According to our ANOVA analysis. the contract type is $0.15 \%$ of the total variance with a Fcal $=0.2126$ at 1 degree of freedom. With a P.value $=0.6457$. we have a $65 \%$ chance of not observing the effect of the contracts on the margin of the actors. We therefore conclude that the analysis of the variance in this case is not significant.

4.5. Link between the mode of transport and the margin of the actors of the sector Table 4.5: Analysis of the influence of the mode of transport on the margin of the sector

\begin{tabular}{|l|c|c|c|c|c|c|}
\hline \multicolumn{1}{|c|}{ Factors } & dol & SS & MSS & F calculated & \% of total variation & P. Value \\
\hline Activity & 5 & 59810 & 11960 & 1.007 & 4.22 & 0.4185 \\
\hline Interaction & 5 & 287800 & 57560 & 4.845 & 20.30 & 0.0006 \\
\hline Mode of transport & 1 & 24870 & 24870 & 2.094 & 1.75 & 0.1514 \\
\hline Residual & 88 & 1045000 & 11880 & & \\
\cline { 1 - 4 } Total & 99 & \multicolumn{5}{|l}{}
\end{tabular}

\section{Source : Data survey}

The results in the previous table show that the mode of transport corresponds to $20.30 \%$ of the total variance with a Fcal $=4.845$ at 5 degrees of freedom and therefore a P. value $=0.0006<0.0001$. The result is not statistically significant. It is concluded that the mode of transport has no effect on the margin of the sector. 4.6. Link between the location variable and the margin of the sector

Table 4.6: Analysis of the influence of location on the margin of the sector.

\begin{tabular}{|c|c|c|c|c|c|c|}
\hline Facteur & Dol & SS & SCM & F calculated & $\%$ de variation & P. value \\
\hline Activité & 2 & 17760 & 8882 & 4.010 & 15.67 & 0.0303 \\
\hline Interaction & 2 & 28620 & 14310 & 6.462 & 25.25 & 0.0053 \\
\hline localisation & 1 & 9398 & 9398 & 4.244 & 8.29 & 0.0495 \\
\hline Residual & 26 & 57580 & 2215 & & & \\
\hline Total & 31 & & & & & \\
\hline
\end{tabular}

According to our table. the location variable is $8.29 \%$ of the total variance with aFcal $=4.244$ at 1 degree of freedom and a $\mathrm{P}$. value $=0.0495$. We therefore have a $5 \%$ probability of perceiving the effect of location on the margin created by the sector. We conclude that the test is statistically significant at the 0.05 level. 4.7. Link of the variable of financial support to the partner on the margin created in the sector

Table 4.7: Analysis of the influence of support on the margin of the sector.

\begin{tabular}{|c|c|c|c|c|c|c|}
\hline Factors & dol & SS & MSS & F calculated & $\%$ de variation & P. value \\
\hline Activity & 3 & 4952 & 1651 & 0.08113 & 0.39 & 0.9699 \\
\hline Interaction & 3 & 354600 & 118200 & 5.809 & 27.63 & 0.0019 \\
\hline Financial Support & 1 & 8406 & 8406 & 0.4131 & 0.65 & 0.5237 \\
\hline Residual & 45 & 915600 & 20350 & & & \\
\hline Total & 52 & & & & & \\
\hline
\end{tabular}

Source : Data survey.

The observation of this table gives us the following elements for the support variable which represents 39\% of the total variance: a Fcal $=0.08$ at 1 degree of freedom with a $\mathrm{P}$. value $=0.5237$. We have $\mathrm{Fcal}<\mathrm{P}$. value. the test is not statistically significant.

\subsection{Evolution of the distribution of the margin in the sector}




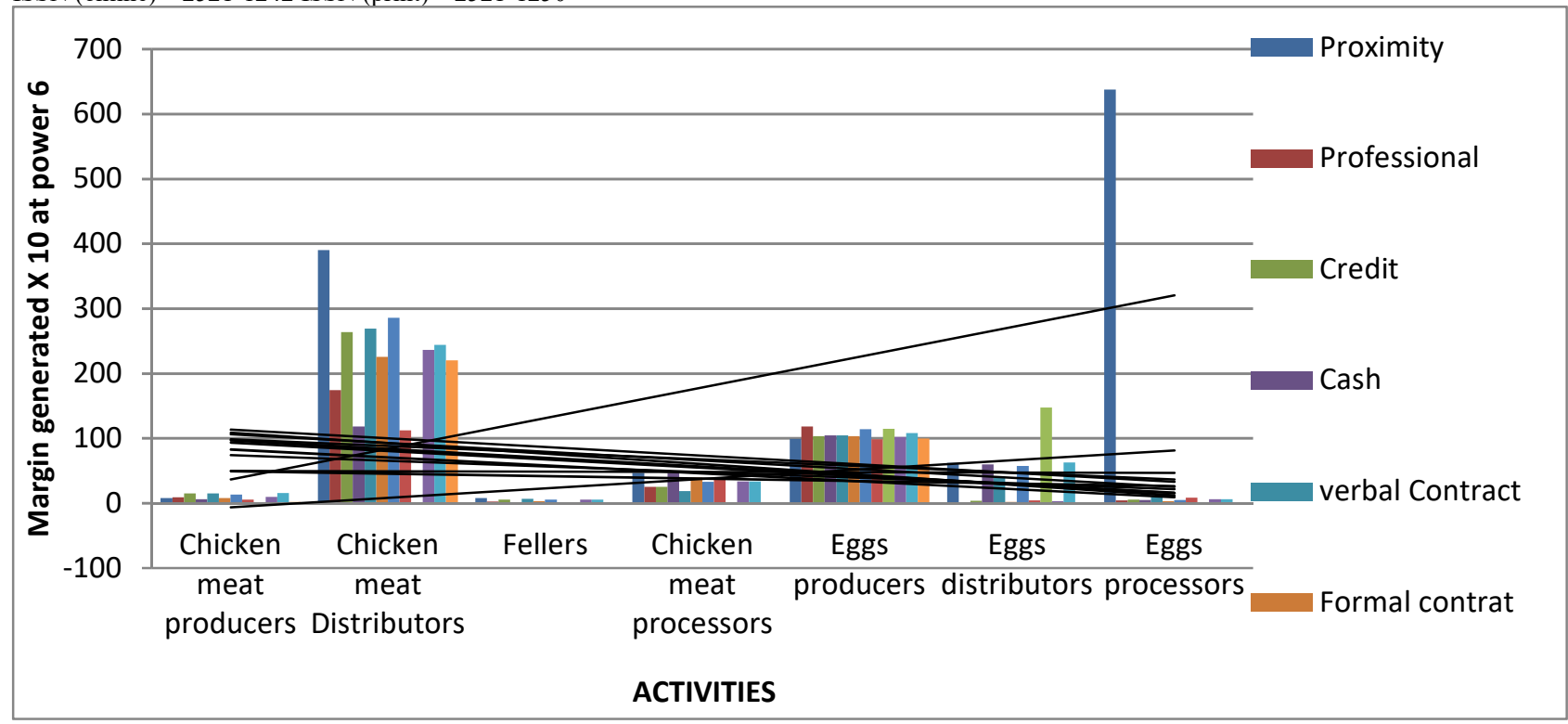

Source: author.

Figure 4.1: Trend curve illustrating the evolution of the margin in the sector from each actor

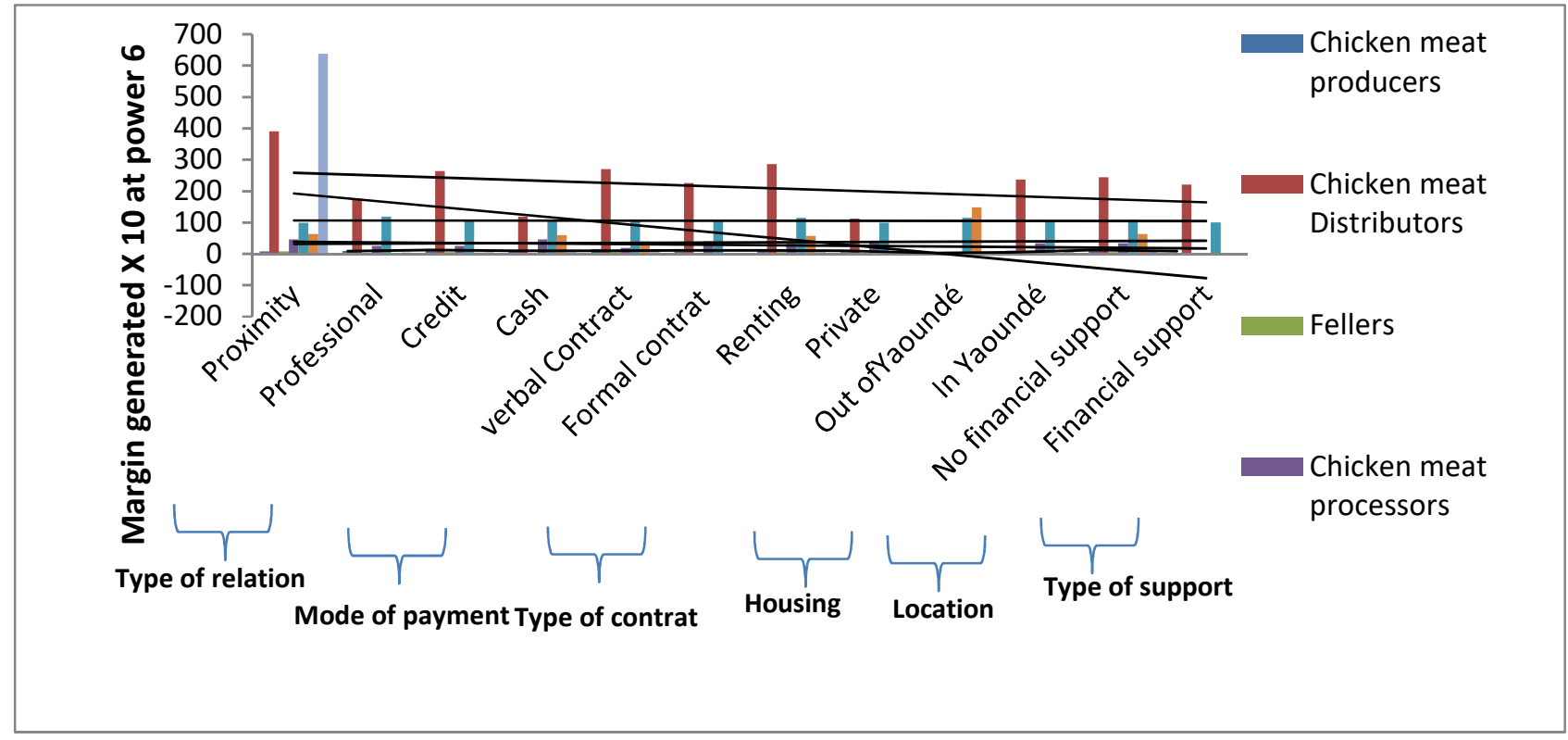

Figure 4.2: Trend curve illustrating the evolution of the margin in the sector from each arrangement

Source: author.

Observation: As illustrated by the graph representing the margin captured by each segment of the value chain and by each arrangement. we find that the trend curve increases from upstream to downstream. We therefore conclude that the distribution of the margin is influenced by the coordination mode between actors.

\subsection{Determination of winners and losers}

In this paragraph. it is a question of identifying the actors who play their part in the different activities and institutional arrangements of the actors of the poultry sector. To do this. the use of histograms will bring out these actors from different value chains.

4.8.1. According to the arrangements between actors. Here. it is a question of evaluating the global margin generated by each activity of the poultry industry. 


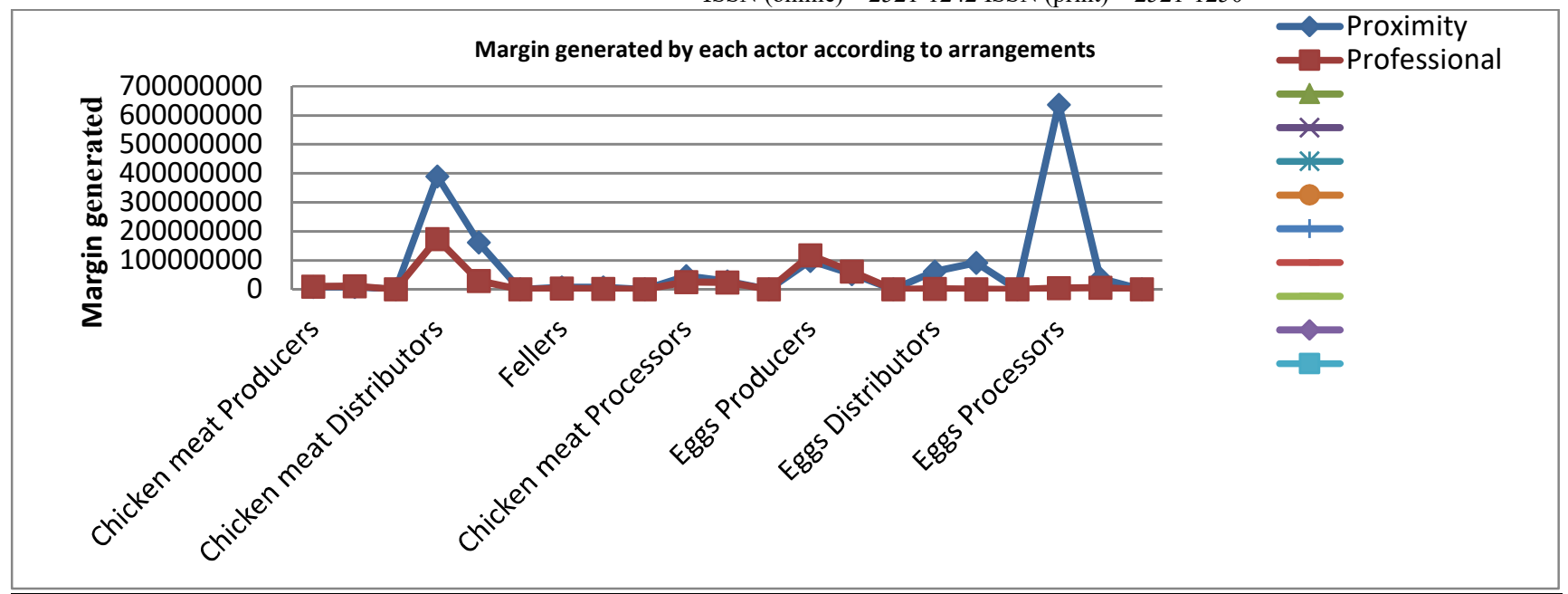

Figure 4.3: Evolution of the margin generated by each activity and according to the actors' arrangements

Source: author.

Observation: We only find that the distribution and processing (broilers) segment as well as the production segment and processing segment (eggs for consumption) have the largest contributions in the margin generated by the sector. We can say that the distributors drive the broiler value chain and the producers drive the egg value chain. In addition. we also conclude that the influence of proximity relations over the margin created in the sector is predominant: it is a relational governance that is omnipresent in the poultry sector of the city of Yaoundé.

\section{Conclusion}

In this paper. our objective was to analyze the shared added value in the poultry sector particularly in the town of Yaounde. To attempt it. we referred to the chain value analyze which allowed us to identify and study the mains chains values inserted in the poultry sector in Cameroon in general. To answer to this problem. we mobilized the Chain Value Theory framework (gereffi. Sturgeon. Humphrey. 2005) which help to identify the power relationship which determine how the human. financial and material resources are organized and circulated in the sector by identifying exchanges coordination modes. We mobilized too the New institutional Economy and the industrial economy to put in evidence the Market structuration. constraints. stakeholder behavior and performance following economic analyzes (accounting). The specificity of site the assets and the frequency developed by the Institutional Neo-Economy allowed to determine the types of products in vigor in the sector and presented the various asymmetries which could face each link of the chain in the transactions between partners. The concept of uncertainty developed here explains the existence of transactions based on site or organizational proximity (custom relations).

The review of the literature has made it possible to demonstrate the evolution of the sector to the value chain to highlighting beforehand the interrelations between the actors and also to identify the link that drive the sector which is none other than the link processors consisting steakhouses for the broiler value chain and bakeries for consumption eggs. However. the determination and distribution of value added in the various values chains does not show any link with the mode of coordination. on the other hand. it is sufficiently related to the relationship of power which structures the transactions. This is due to the fact that some actors are interfering in the activity of their partner. other prefer to exchange with partner they master (ethnic. friendly. family) to reduce the risks of uncertainty and in turn. increase their income.

\section{References}

1. Annie Royer. (2009). Analyse économique néo-institutionnelle de la mise en marché collective. Application au secteur laitier du Québec. Economies and finances. Université Panthéon-Sorbonne - Paris I.. French.

2. Association citoyenne de défense des intérêts collectifs (ACDIC). (2005). L'importation massive de poulet congelé au Cameroun : état des lieux. enjeux et alternatives. Rapport d'études.

3. Association citoyenne de la défense des intérêts des consommateurs (ACDIC). 2004. 2005. Poulets congelés. comprendre le phénomène au Cameroun. 
Financial Markets, Institutions and Risks, Volume 3, Issue 2, 2019

ISSN (online) - 2521-1242 ISSN (print) - 2521-1250

4. Banque mondiale (BM). (1994. 2004 et 2007). Retrieved from:http://www.banquemondiale.org

5. Bencharif A. et Rastoin J.L. (2007). Concepts et méthodes de l'analyse de filières agroalimentaires: application par la chaîne globale de valeur au cas des blés en Algérie. Série WorkingPapers $n^{\circ} 200707$. Montpellier. UMR MOISA.

6. Courade. G. (2005). L'insécurité alimentaire urbaine au Cameroun dans son contexte. Contribution à l'Atelier du 21 au 23 mars 2005 sur l'approvisionnement et l'alimentation dans les villes du Cameroun. organisé par la FAO. le JCAD et le Service de Coopération et d'Action Culturelle de l'Ambassade de France au Cameroun. Publié dans le Bulletin trimestriel Enjeux n²3. Avril-Juin 2005. de la Fondation Paul AngoEla (FPAE).

7. Cyprien Awono Bessa. (2008). Les déterminants économiques de la consommation urbaine de poulet de chair dans les pays du Sud: cas du Cameroun et d'Haiti.

8. FAO. State of Food Insecurity in the World (SOFI). (2004). L'état de l'insécurité alimentaire dans le monde : Suivi des progrès accomplis en vue de la réalisation des objectifs du Sommet mondial de l'alimentation et de la Déclaration du Millénaire. Rapport FAO. 2004.

9. Gereffi G. (1999). International trade and industrial upgrading in the apparel commodity chain ». Journal of International Economics. 48. 1. 37-70.

10. Gereffi G. (2001). Beyond the Producer-driven/Buyer-driven Dichotomy. The Evolution of Global Value Chains in the Internet Era. IDS Bulletin. 32. 3. 30-40.

11. Gereffi G. etKorzeniewicz M. (1994). Commodity chains and global capitalism. Westport. Conn. Greenwood Press. Contributions in economics and economic history.

12. Gereffi G. Humphrey J. et Sturgeon T. (2005). The governance of global value chains. Review of International Political Economy. 12. 1. 78-104.

13. Hopkins et Wallerstein. (1977). Théorie des systèmes-monde et chaînes de commodités dans Sociologie et développement.

14. Hugon P. (2003). Economie de l'Afrique. La Découverte. 123 p.

15. Institut National de la Statistique (INS). (juillet 2014). Flambée de $14.2 \%$ des prix des transports.

16. Institut National de la Statistique. (2007). 3è Recensement Général de la Population Humaine du Cameroun.

17. Interprofession Avicole du Cameroun (PAVIC). (2014). Résultat de la Campagne 2014.

18. Jenifer Bair. (2010). Les cadres d'analyse des chaînes globales.

19. Kingsbury. D. (2010). Questions de fond relatives aux chaines de valeur. aux opportunités et à la croissance: rôles des projets financés conjointement par le FIDA. Atelier régional sur l'exécution des projets en Afrique de 1'Ouest et du Centre. 8-11 Novembre 2010. Dakar. Sénégal. 17p.

20. Ludovic Temple et Fréderic Lançon. (2011). Actualisation du concept de filière dans l'agriculture et l'agroalimentaire.

21. Ministère de l'Elevage. des Pêches et des Industries Animales (MINEPIA). (2009). Schéma directeur pour le développement des filières agricoles du Cameroun.

22. Moustier P. (2009). Gouvernance et performance des filières alimentaires au Vietnam. Economies et sociétés. 43. 11. 18351855.

23. North. Douglass C. (1981). Structure and Change in Economic History. New-York. W.W. Norton. 240 p.

24. North. Douglass C. (1990). Institutions. Institutional Change and Economic Performance: Cambridge University Press.

25. Programme d'Appui à la Compétitivité des filières agricole (PACA). (2013). Rapport annuel du PACA

26. Stiglitz. (2002). La grande désillusion. Editions Fayard. 324 p.

27. Teleu Emile et Ngatchou Alexandre (2006). Première évaluation du secteur avicole du Cameroun : structure et importance du secteur avicole commercial et familial pour une meilleure compréhension de l'enjeu de l'Influenza aviaire. Rapport des consultants nationaux.

28. Teguia A et al. (2014). Contribution de l'Aviculture à l'émergence du Cameroun lors du Salon de l'aviculture International du Cameroun à Yaoundé.

29. Temple Ludovic. (2014). Economie des filières et d l'innovation du secteur agricole et alimentaire. Cours EDRA Yaoundé 2 - Cirad.

30. WILLIAMSON Oliver E. (1975). Markets and Hierarchies: Analysis and Antitrust Implications. New-York: Free Press.

31. Williamson Oliver E. $(1975 ; 1985)$. sur la théorie des jeux et l'analyse des coûts des transactions. 